Article

\title{
Executive Compensation and Firm Performance in New Zealand: The Role of Employee Stock Option Plans
}

\author{
David K. Ding ${ }^{1,2, *}$ and Ya Eem Chea ${ }^{3}$ \\ 1 Lee Kong Chian School of Business, Singapore Management University, Singapore 178899, Singapore \\ 2 School of Economics and Finance, Massey University, Auckland 0745, New Zealand \\ 3 Securities and Exchange Commission Ministry of Economy and Finance, Phnom Penh 12107, Cambodia; \\ c_yaeem@secc.gov.kh \\ * Correspondence: d.ding@massey.ac.nz or davidding@smu.edu.sg
}

Citation: Ding, David K., and Ya Eem Chea. 2021. Executive Compensation and Firm Performance in New Zealand: The Role of Employee Stock Option Plans. Journal of Risk and Financial Management 14: 31. https://doi.org/10.3390/ jrfm14010031

Received: 23 November 2020 Accepted: 7 January 2021

Published: 11 January 2021

Publisher's Note: MDPI stays neutral with regard to jurisdictional clai$\mathrm{ms}$ in published maps and institutional affiliations.

Copyright: $(\odot 2021$ by the authors. Licensee MDPI, Basel, Switzerland. This article is an open access article distributed under the terms and conditions of the Creative Commons Attribution (CC BY) license (https:// creativecommons.org/licenses/by/ $4.0 /)$.

\begin{abstract}
We examine the role of employee stock option plans (ESOPs) in mitigating agency problems in New Zealand firms. We find that ESOPs have a significant and positive effect on firm performance relative to their non-ESOP counterparts. This relation appears within a year from the first ESOP announcement, and for two to four years after the announcement. Our results show that ESOPS improve corporate performance by 10 times the cost of the ESOPs' adoption in the first year of issue. The improvement persists for four years after the first issuance. These findings confirm the effectiveness of employee stock option plans for companies issuing ESOPs compared with companies that do not issue ESOPs, and show how much the value creation of ESOPs contributes to these firms.
\end{abstract}

Keywords: employee stock option plans; executive compensation; firm performance; New Zealand

\section{Introduction}

Attempts to determine an effective tool of executive compensation that is aligned with the best interests of shareholders have been a long-standing topic of discussion among academicians, researchers, investors, and corporations. Executive compensation is recognized as a cashless incentive that reduces the agency problem between shareholders and managers. Shleifer and Vishny (1997) suggest that incentive contracts are related to addressing agency problems in the field of corporate governance. Likewise, Jensen and Murphy (1990) show that, on average, chief executive officers (CEOs) are awarded $\$ 3.25$ for every $\$ 1000$ increase in shareholder value. The corporate practice of executive incentives develops into various forms, including share-based schemes and employee stock option plans (ESOPs). ESOPs in New Zealand are not yet broadly implemented, or widely analyzed by researchers. About one-third ${ }^{1}$ of New Zealand listed firms prefer to adopt ESOPs to reward their employees. To inform about the effectiveness of ESOPs, we address the effectiveness of employee stock option plans among New Zealand firms and how much value ESOPs contribute to their performance.

The extant literature on ESOPs includes the studies of Coughlan and Schmidt (1985), Murphy (1985), Jensen and Murphy (1990), Abowd (1990), and Leonard (1990), who first investigated the relationship between executive compensation and firm performance. Subsequent researchers have examined option grants for top management and showed that ESOPs are an effective tool for aligning the interests of managers with shareholder wealth. For example, for one and a half decades, firms and their shareholders witnessed sharp growth in ESOPs, leading to an increase in CEO pay performance sensitivity, as documented by Hall and Liebman (1997). Langmann (2007) finds that significant abnormal returns on ESOP announcement dates are greater than their associated costs among German firms. Japanese investors earn a two-percent abnormal return during ESOP announcements

\footnotetext{
1 From the initial data collection, 59 firms have adopted ESOPs, which is approximately one-third of the sample firms.
} 
(Kato et al. 2005). Ding and Sun (2001) report support for the positive impact of ESOPs on firm performance among Singaporean firms.

Despite the benefits that ESOPs can create for firms, there are some drawbacks since ESOPs may not always be executed appropriately. Overuse of ESOPs and costly adoption are examples of ineffective ESOPs. Tian (2004) discusses grant size impacts of ESOPs and find that an increase in the size of incentive grants may lessen an ESOP's effect on stock price maximization when the total value of the ESOPs exceeds a proportion of the firm's total capital value. Another factor is when the value of ESOPs to companies is lower than the cost of their establishment. Hall and Murphy (2003) find that this happens when managers and directors of a company perceive the expense of ESOPs as the cost of accounting and cash flow consideration rather than the economic cost of the incentive. Therefore, issuing more grants would hurt the company's financial position.

This paper addresses two important questions. The first investigates whether ESOP issuers outperform their non-ESOP counterparts. The second measures the size of the value contribution by firms with ESOPs. We perform our analysis within the context of listed firms on the New Zealand Stock Exchange (NZX). The companies listed on the NZX have mostly established more than one incentive plan to reward their employers for greater achievement. Among those types of incentives, share-based plans or performance-rights schemes are commonly seen in New Zealand firms, followed by stock option incentives. Share-based schemes allow contractors to purchase ordinary shares of the company at a discount rate. Firms deliberately adopt share-based programs to match executive performance to share price. Ideally, share-based compensation may attract management teams, because owning a stake in the company causes them to act more like an owner. As share owners, these skillful teams, possessing human capital resources, will devote themselves to achieve profit maximization and, at the same time, increase the equity value. Morgenson (1998) states that about 13\% of the common stocks of the 200 largest US corporations are given to managers as rewards. This form of incentive is referred to as performance-right plans. Some New Zealand companies have recently started to use performance-right plans in lieu of cashless share-ownership plans, as the new plans now set additional specific hurdles for employers to meet. For instance, if this year's revenue increases by $1 \%$ with respect to last year, the employees granted the options can exercise their rights to purchase shares at a rate below the market price and make a profit on the same day. In recent years, the plans have become widespread among New Zealand listed companies.

Another cashless incentive form that is being practiced by New Zealand firms is employee stock option plans, which are used to reward both senior and junior level staff. Companies remunerate those who satisfy the criteria officially approved by the Board of Directors. Employee stock option programs provide the holders with the opportunity to make profit only if any difference between the market price and the exercise price is greater than zero. Normally, this is also an incentive to increase the company's share price. As in performance-right plans, some companies may set vesting periods that allow granted employees to exercise a certain number of options. For example, within one year after issuing ESOPs, option holders are able to exercise $25 \%$ of their total grants, and another two years they are allowed another $25 \%$ of their total grants, and so on until the entire grant has been exercised. Some only allow their employees to exercise the whole package of ESOPs until a scheduled maturity date. For example, for a five-year maturity option, granted employees must exercise the entire grant within a specific period stated in the option contracts, or the option will lapse. In some cases, the ESOP issuing companies allow option owners to exercise options to buy ordinary shares in their companies.

Our findings add to the literature on the role of ESOPs granted to executive teams in increasing firm value, while reducing agency problems. We determine whether ESOPs may have any positive influence on firm operation and check for robustness of the findings. We further analyze the degree of value creation of ESOPs on firm performance. We show that ESOPs improve corporate performance by 10 times the cost of the ESOPs' adoption in the first year of issue. This improvement persists for four years after the first issuance. 
These findings confirm the effectiveness of employee stock option plans for companies issuing ESOPs compared with companies that do not issue ESOPs, and how much the value creation of ESOPs contribute to these firms.

This article is organized as follows. The next four sections cover the institutional background of the New Zealand Stock Exchange (NZX), literature review, data and univariate analysis, and research questions and methodology. Section 6 discusses our multivariate results, and robustness checks are provided in Section 7. Section 8 concludes.

\section{Institutional Background of the NZX}

The NZX was launched in 1974 as a publicly owned company with a half share of the ownership in Link Market Services Limited. It is modelled as a self-regulating organization, making it a market regulator and operator at the same time. This means that the NZX issues rules for its own market operation and practice through its enforced and enhanced regulatory legislation, and in-place policy and guidelines. In the process of regulating, the NZX seeks public opinion and feedback to ensure that the best interests of both shareholders and issuers are considered. The NZX's tasks involve protecting shareholders from unfairness and inequitable actions of the firm, providing timely disclosure information, investigating any market hazards, and ensuring cost compliance effectiveness. Overall, all listed companies are regulated under this market supervision to ensure fairness, transparency, efficiency, and competitiveness.

The NZX currently runs three capital markets: The New Zealand Stock Market, the New Zealand Debt Market, and the New Zealand Alternative Market. The current study considers only stocks that are listed on the main board of the New Zealand stock market. As of 2015, there are 162 listed companies on the main board. ${ }^{2}$ The main board trades the stock of larger firms in the New Zealand market. The normal trading hours of the NZX are from 10:00 a.m. to 4:45 p.m., plus one extra hour for each pre-open and pre-close trading hour. The market is open on working days, from Monday to Friday. On average, the trading volumes of the NZX are 34 million shares per day, with a market capitalization of approximately NZ $\$ 101$ billion per day. ${ }^{3}$

ESOPs are largely used by firms listed on the main board. Emanuel (2005) reveals that most ESOP packages in New Zealand only account for 1-2\% of the issuing firm's total outstanding ordinary shares. In 2007, a provision of NZ IFRS-2 imposes new requirements for listed firms to disclose the fair value of the share-based compensation issued to their employees. The fair value is treated as an expense to the companies and must be reported in the annual report available to the public.

\section{Literature Review}

Coase (1937), Jensen and Meckling (1979), Fama and Jensen (1983a, 1983b) document that agency problems exist when the managers of firms funded by investors develop ill intentions towards both the ownership and control of the firms; this is referred to as power concentration. The arguments of how large an optimal compensation package should be to ensure that managers act in the best interests of their shareholders, rather than their self-interest, is controversial. As illustrated by Ross (1973), Stiglitz (1975), Mirrlees (1976), a manager's risk aversion, the importance of his decisions to the firm, and his ability to pay for cash flow ownership up front determine the optimal incentive contract. Shleifer and Vishny (1997) suggest that a better solution is to grant a manager a highly contingent, long-term incentive contract ex ante to align his interests with those of investors. Murphy (1999) also discusses the relation between CEO pay and firm performance.

2 The number of listed companies on the main board of the NZX are recently extracted from the NZX main board website in June 2015: https: //www.nzX.com/markets/NZSX/securities.

3 These figures are extracted from the NZX website on 1 July 2015: https:/ / www.nzX.com/markets/NZSX. 


\subsection{Optimal ESOPS}

Among the various forms of managerial incentive contracts, stock options are popular incentives among companies and their shareholders to encourage better performance. Jensen and Murphy (1990) examine the sensitivity of stock options and firm performance and find a positive relation between executive pay and firm wealth. Likewise, Brickley et al. (1985), DeFusco et al. (1990), and Si et al. (2020) demonstrate that there is a positive market reaction to the implementation of ESOPs. Hassan and Hoshino (2007) investigate factors that cause shareholders to vote against CEO pay through shareholder "say-on-pay" voting. They provide evidence that shareholders will be concerned about CEO pay when they are making a loss; however, when the firm performance is above average, shareholders affirm CEO pay, regardless of whether it is high or low. Thus, in a loss position, shareholders will exercise their votes against excessive CEO pay. This could also imply that shareholder participation helps to hold ESOPs at the level of their firm value.

\subsection{Benefits of ESOPs}

Many scholars agree that companies should reward the performance of management teams with stock option grants. Hall and Liebman (1997) confirm that ESOPs create value for practitioners. Some corporations find that this incentive is quite convenient since it is a cashless approach that allows companies to reduce the cost of compensation for the time being. It saves firms from any monetary cost until the option realizes the cost, or until the holders of the options exercise the grants, so that firms can make use of the time opportunity and the retained cash for extensive investment. Nevertheless, this does not mean that granting longer maturity ESOPs can always lower the cost of executive payoffs, as in some cases of more risk averse and undiversified managers, longer maturity ESOPs are not better than earlier exercisable ESOPs. Earlier exercisable ESOPs will increase these types of manager value, as well as shareholder value, by reducing cost to firms (Hall and Murphy 2002). Hall and Murphy (2002) explain that a cost reduction is derived from a decrease in the right-hand tail of firm payoffs to executives, because their holding on options cuts large firm payoffs when there is a noticeable increase in the stock price of the firm. In the management literature, Kurland (2018) finds that the use of ESOPs benefits the corporation due to enhanced employee engagement and creation of a meaningful work environment.

\subsection{Drawbacks of ESOPS}

ESOPs can be controversial. Yermack (1997) suggests that stock options are frequently not a strong enough incentive to influence managers to devote their time and effort to reaching the optimal profit for the firm. ESOP rewarding sometimes turns out to encourage the mechanism of self-dealing. He justifies this argument that stock options would be granted to managers just prior to good news announcements, but not granted until after bad news announcements. Additionally, this form of incentive will only motivate managers to act in the short-term interests of shareholders. Evidence from Aboody and Kasznik (2000) shows that managers will exercise options merely for a sake of short-term targets. More recently, Riaz et al. (2017) highlighted potential drawbacks such as the dilution of the value of shares and ownership from the ESOPs are exercised.

\subsection{ESOPs and Firm Performance}

Hillegeist and Penalva (2004) show a significantly positive relationship between employee stock option grants and firm performance as estimated by Tobin's Q and ROA. Employing stock returns as a proxy for firm performance, DeFusco et al. (1990) find that the use of ESOPs improves share price. Hassan and Hoshino (2007) study 1600 crosssectional firms listed on the Tokyo stock exchange and find that a release of option grant announcement increases the productivity and market performance of firms. Ding and Sun (2001) suggest a significant positive improvement of firm performance in the Singapore market during announcement of ESOPs. 
On the contrary, there are also some researchers who have investigated the failure of stock option grants in promoting better corporate performance. For example, Core and Guay (2001) offer the contradictory explanation that the use of ESOPs fails to motivate executives or encourage a stronger productive workforce in the US markets. They explain that this is because managers make a false decision to grant the options when the economic cost significantly exceeds the cost of the incentive establishment. Meulbroek (2000) suggest that the real cost of ESOPs could be the inevitable deadweight cost to the issuers since financial practice focuses on the ESOP's benefits alone and ignores the existence of its cost. Triki and Ureche-Rangau (2012) provide evidence that a sample of French companies does not support the notion that option grants positively contributes to accounting and market performance.

Popescu and Popescu (2019) suggest that green and sustainable finance that meet the requirements of corporate social responsibility are related to the financial performance of a firm. It can therefore be envisaged that sustainable ESOPs can enhance firm value. Paquette (2010) shows that sustainable ESOPs can create shareholder value.

\section{Data and Univariate Analyses}

We collect all ESOP data of NZX-listed companies from Datastream, Bloomberg, and NZX Company Research until 2015. We identify companies that first announced and issued ESOPs for executives. Non-ESOP firms are first matched with ESOP firms by industry, then by firm size if a matching industry is not found. Non-ESOP firms with the closest match are selected. The ESOPs are hand-collected from the annual reports disclosed on the NZX Company Research website. We first identify 59 listed companies that first announced their adoption of ESOPs. After excluding financial institutions and firms with pre-existing ESOPs prior to their listing date, 42 companies remain. These are matched with 42 nonESOP firms, giving us a final sample of 84 companies across six industries. In total, there are 504 firm-year observations. ${ }^{4}$ In each firm-year, we categorize each observation into year $-1,0,1,2,3$ and 4, relative to each firm's first ESOP announcement. Pooling the 84 firms together allows us to compare the performance of ESOP versus non-ESOP firms.

From the annual reports of ESOP-issuing firms, we extract each ESOP's vesting period, maturity date, exercise price, and the total grants held by executives. The study period is limited to five firm-year observations due to constraints on data availability and the maturity of ESOPs. Vesting period effects are captured to evaluate how influential ESOPs are on firm performance when they are considered. Vesting periods are recorded for each company and grouped into four categories of vesting periods: one, two, three, and other years. The maturity date of ESOPs plays a key role in filtering the intrinsic value of ESOPs. When an ESOP expires at its maturity date, it will no longer have any intrinsic value. Therefore, this drives firm-year observations to drop dramatically over the long horizon. The intrinsic value of ESOPs is calculated by taking the difference between its market and exercise price and then deflating this by the market price. This value will be zero if the market price is lower than the exercise price. The remaining information pertaining to firm-specific characteristics and industry variables are drawn from Datastream and Bloomberg. These include the monthly stock returns and annual ROA, ROE, total assets, total equity, market capitalization, long-term debt, and dividends.

Table 1, Panel A, reports the descriptive statistics of 42 companies with ESOPs and 42 companies without ESOPs for a total of 84 firms. A majority of 48 companies in the sample belong to the services industrial sector. This is followed by the goods industrial sector, with 18 firms. This shows that employee stock option grants are very popular among companies providing service products, and these companies have a large influence on the New Zealand market. Panel B of the table reports the number of ESOP companies

4 Total firm-year observations account for 84 firms over 6 years for a total of 504 firm-year observations. Two ESOP companies in our sample do not have a perfect match within the same industry. As such, the matching for these two firms is based on firm size across different years. We can confirm that there are no timing overlaps in the sample. 
which have set up vesting periods. As shown, a three-year vesting period accounts for approximately $43 \%$ of the firms, with others having one-year or two-year vesting periods after their first issuance of ESOPs.

Table 1. Sample data. The table shows the total firm observations in the sample. There are six industries, with the ESOP announcing firms and non-ESOP firms first being reported together in Panel A. Panel B depicts the vesting periods, which are categorized into three periods: 1 year, 2 years, 3 years, and other.

\begin{tabular}{|c|c|c|c|c|c|}
\hline \multicolumn{6}{|c|}{ Panel A: Industry Summary } \\
\hline Industry & \multicolumn{5}{|c|}{ Number of Companies } \\
\hline Primary & \multicolumn{5}{|c|}{10} \\
\hline Investment & \multirow{2}{*}{\multicolumn{5}{|c|}{2}} \\
\hline Energy & & & & & \\
\hline Services & \multicolumn{5}{|c|}{48} \\
\hline Goods & \multicolumn{5}{|c|}{18} \\
\hline Property & \multicolumn{5}{|c|}{2} \\
\hline Total & \multicolumn{5}{|c|}{84} \\
\hline \multicolumn{6}{|c|}{ Panel B: Vesting Periods } \\
\hline \multirow{2}{*}{ Type of Sample } & \multicolumn{4}{|c|}{ Vesting Period } & \multirow{2}{*}{ Total Sample Size } \\
\hline & 1 Year & 2 Years & 3 Years & Other & \\
\hline $\begin{array}{c}\text { Companies with } \\
\text { Employee Stock } \\
\text { Option Plans }\end{array}$ & 10 & 9 & 18 & 5 & 42 \\
\hline Percentage & $23.81 \%$ & $21.43 \%$ & $42.86 \%$ & $11.90 \%$ & $100.00 \%$ \\
\hline
\end{tabular}

Table 2 describes the means and medians of the three main proxies of firm performance, Tobin's $Q, R O A$, and ROE. In the table, year -1 is the year prior to the first announcement of ESOPs, year 0 represents the year of the first announcement of ESOPs, and year 1 to year 4 refer to one to four years after the announcement. In addition to significant and positive results in the means and medians of Tobin's $Q$, the mean differences suggest that the firm performance of ESOP issuers is at its highest level of 1.83 during the year of the first announcement of ESOPs. The medians of the differences show that $70 \%$ of the total sample improves for firms with ESOPs compared with their non-ESOP counterparts. This performance decreases slightly in the subsequent years. The reported mean and median differences in Tobin's $Q$, as a proxy for firm performance, provides initial evidence that firms which first announce ESOPs have greater value than those that do not.

The mean differences in ROE and ROA between firms with and without ESOPs are not statistically significant. Some years have negative mean differences, including the year of their first announcement. These findings are consistent with those of Cheffou (2007) and Triki and Ureche-Rangau (2012), who find that there is no association between the accounting performance and ESOPs; however, ESOPs are positively related with Tobin's Q. 
Table 2. Descriptive statistics. This table describes the statistical means and medians of the dependent variables of firm performance (ROA, ROE and Tobin's Q) for the companies with ESOPs and companies without ESOPs. The differences of the means, median, and the t-statistics and $p$-value between both parties are also reported. Year -1 refers to a year prior to the first announcement date of ESOPs; Year 0 is a year of the first announcement; and Year 1 to Year 4 represent a range of years from one year to four years after the announcement. * ${ }^{* *}$ and ${ }^{* *}$ are $90 \%, 95 \%$ and $99 \%$ levels of significance, respectively.

\begin{tabular}{|c|c|c|c|c|c|c|}
\hline \multirow{2}{*}{$\begin{array}{c}\text { Firm } \\
\text { Performance }\end{array}$} & \multirow{2}{*}{ Year } & \multicolumn{2}{|c|}{ Companies with ESOPs } & \multicolumn{2}{|c|}{$\begin{array}{c}\text { Companies without } \\
\text { ESOPs }\end{array}$} & \multirow{2}{*}{$\begin{array}{c}\text { Mean } \\
\text { Difference }\end{array}$} \\
\hline & & Mean & Median & Mean & Median & \\
\hline \multirow{6}{*}{ Tobin Q } & -1 & 1.73 & 0.99 & 1.13 & 0.73 & $0.59 *$ \\
\hline & 0 & 2.98 & 1.41 & 1.15 & 0.71 & $1.83^{* * *}$ \\
\hline & 1 & 2.36 & 1.37 & 1.26 & 0.67 & $1.10^{* * *}$ \\
\hline & 2 & 2.12 & 1.26 & 0.83 & 0.63 & $1.29 * * *$ \\
\hline & 3 & 1.54 & 0.91 & 0.94 & 0.78 & $0.60^{* *}$ \\
\hline & 4 & 2.21 & 0.89 & 1.14 & 0.68 & $1.07 * *$ \\
\hline \multirow{6}{*}{ ROA } & -1 & 0.00 & 0.03 & 0.05 & 0.07 & -0.05 \\
\hline & 0 & -0.30 & 0.05 & 0.02 & 0.05 & -0.32 \\
\hline & 1 & 0.00 & 0.05 & 0.01 & 0.05 & -0.01 \\
\hline & 2 & 0.03 & 0.04 & -0.02 & 0.04 & 0.06 \\
\hline & 3 & 0.03 & 0.05 & 0.06 & 0.05 & -0.03 \\
\hline & 4 & 0.03 & 0.04 & 0.01 & 0.05 & 0.02 \\
\hline \multirow{6}{*}{$\mathrm{ROE}$} & -1 & 0.04 & 0.06 & 0.09 & 0.11 & -0.05 \\
\hline & 0 & -0.30 & 0.08 & 0.05 & 0.08 & -0.36 \\
\hline & 1 & 0.02 & 0.08 & 0.02 & 0.09 & -0.00 \\
\hline & 2 & -0.13 & 0.08 & -0.18 & 0.08 & 0.04 \\
\hline & 3 & 0.06 & 0.09 & -0.05 & 0.08 & 0.10 \\
\hline & 4 & -0.01 & 0.08 & -0.04 & 0.08 & 0.02 \\
\hline
\end{tabular}

\section{Research Questions and Methodology}

\subsection{Research Questions}

We investigate two main research questions. The first explores whether ESOPs are an effective incentive to align managers' interests with shareholder wealth in companies initially announcing ESOPs in New Zealand. The effects of the first ESOP announcement may be perceived as good news by investors. Yermack (1997) finds a positive relationship between the long-term incentive ESOP programs for executives and firm performance. This study is similar to those of Aboody and Kasznik (2000) and Core and Guay (2001), who focus on the long-term impacts of ESOPs on firm value. A significantly positive relationship between ESOPs and firm performance would indicate that companies with ESOPs outperform their non-ESOP counterparts. This would imply that ESOPs are an effective incentive tool to mitigate the agency costs between shareholders and managers.

The second research question examines how much value ESOPs add to the firm. According to Aboody (1996) ESOPs' intrinsic value plays a key role in reducing managers' control on the entrenchment of funds, thereby increasing the value of the firm. He reaffirms the existing findings that issuing ESOPs are positively correlated with firm value. We therefore determine the value that ESOPs have created for the firms. We do this by measuring the intrinsic value of ESOPs, which is the ratio of the difference between the market price of the firm's stock and the option's exercise price to the stock price. The advantage of this measure, as opposed to using the traditional Black-Scholes option pricing model (Black and Scholes 1973), is that the Black-Scholes option pricing model cannot capture the value of non-transferable ESOPs. 


\subsection{Research Method}

The question of how effective ESOPs are for issuers remains ambiguous and mixed. In this paper, we address whether ESOPs are an effective tool for mitigating the agency problems and how much value ESOPs contribute to the firm. We employ Tobin's Q as a proxy for firm value. A positive surge in Tobin's $Q$ would be reflective of the effectiveness of ESOPs in mitigating agency costs. After determining that ESOPs add to firm value, we then measure the extent of the value that is added. Robustness checks are performed by using alternative proxies for firm performance, i.e., ROA and ROE, and controlling for the vesting periods.

An ESOP's intrinsic value is estimated right after the first issuing date of the ESOPs by taking the difference between the market price and exercise price, scaled by the same market price:

$$
\text { ESOPs Intrinsic Value } i t=\frac{\text { Market Price }_{i t}-\text { Exercise Price }_{i}}{\text { Market Price }_{i t}}
$$

where ESOPs Intrinsic Value ${ }_{i t}$ is the option's intrinsic value for stock $i$ at time $t$; Market Price $_{i t}$ is the closing price of stock $i$ at time $t$; and Exercise Price ${ }_{i}$ is the strike price of the first ESOP adoption of stock $i$.

Hillegeist and Penalva (2004) employ two proxies for firm performance: Tobin's Q and ROA. They report a positive and significant effect of employee stock option grants on firm value using both measures. Similarly, Aboody and Kasznik (2000) and DeFusco et al. (1990) investigate the relationship using stock returns while ROE is used by Triki and Ureche-Rangau (2012), Cheffou (2007). We employ Tobin's Q as the primary measure of firm performance, while ROA, ROE, and the stock returns serve as robustness checks to validate our findings.

Tobin's $Q$ is estimated by taking the current market capitalization divided by total assets. ROA is the ratio of net income to total assets, and ROE is the ratio of net income to total shareholders' equity. The three proxies are computed as:

$$
\begin{gathered}
\text { Tobin/s Q }=\frac{\text { Current Market Capitalisation }}{\text { Total Assets }} \\
\text { ROA }=\frac{\text { Net Income }}{\text { Total Assets }} \\
\text { ROE }=\frac{\text { Net Income }}{\text { Total Shareholders/ Equity }}
\end{gathered}
$$

The annualized rate of return is calculated by taking a geometric average of the monthly rate of return. The monthly rate of return is computed as:

$$
\text { Month } \operatorname{Return}_{i t}=\frac{P_{i t}}{P_{i t-1}}-1
$$

where $P_{i t}$ is the adjusted price of stock $i$ at time $t$; and $P_{i t-1}$ the adjusted price of stock $i$ at time $t-1$. We then annualize the monthly returns by their geometric mean:

$$
\text { Annualized Return } \text { Rit }=12 \times\left(\left[\pi\left(1+\text { Month Return }_{i t}\right)\right]^{1 / 12}-1\right)
$$

where $\pi$ is a product of Annualized $\operatorname{Return}_{i t}$.

Following Triki and Ureche-Rangau (2012), we examine the size of executive option grants to test whether the companies overuse ESOPs grants to reward their executives. In lieu of taking the total grant size of ESOPs, we capture the total grant size for executives, since a large amount of grants are issued to reward executives who make important financial decisions in their firms. An executive grant size is the natural logarithm of the total aggregate of ESOP grants. If the grant size is negatively related to firm performance, it can be implied that firms over-reward their managers, and vice versa. 
Theoretical arguments emphasize how industry diversification affects firm operation. According to Core and Guay (2001), even after adjusting for industry, firms that reward their employees with ESOPs continue to witness a growth in performance. Therefore, we expect the industry in which companies are operating to have an influence on their overall performance. In our study, we control for industry effects.

We use vesting period dummy variables to determine whether the exercised stock options have any effects on corporate performance. Controlling for vesting period effects allows us to see how strong the effects of ESOPs are on firm performance. As suggested by Aboody (1996), who investigates the vesting effects on the relationship between ESOPs and firm value, we find that a positive relation holds until the first option vesting period before witnessing a negative impact of the option in the latter vesting periods. According to Aboody's interpretation, once the options arrive at the vesting period, they are likely to be exercised. Therefore, the value of ESOPs becomes faint when the options move farther away from the original date of their first granting. If Aboody (1996)'s argument holds true, we would observe stronger effects of ESOPs on firm performance in those years when many companies set vesting periods.

It is common for firms to set vesting periods for exercisable options; for instance, when option holders are allowed to exercise $25 \%$ of their total option grants on its first anniversary, and another $25 \%$ on its second anniversary, etc. Hall and Murphy (2002) conclude that a short vesting period may be appropriate, and is more common for firms than long vesting periods, due to the offsetting efficiency cost of ESOPs. The effects of ESOPs may appear at the time or because option holders decide to exercise their options. Huddart and Lang (1996) also inspect the effect of early exercisable options that seem to be a key implication for understanding ESOPs and examine the determinants of exercisable activity such as firm vesting schedules.

We expect firm performance, as measured by Tobin's $Q$, to be affected by firm-specific characteristics such as firm leverage, overinvestment problems, and firm size. As such, we consider them in our model. We first test the question whether ESOPs are an effective incentive for the alignment of managers' interests to shareholder wealth in companies that make their first announcement of ESOPs compared with non-ESOP companies. We investigate whether ESOP firms outperform their non-ESOP counterparts. The following model is tested:

Firm Performance $=\beta_{0}+\beta_{1}$ OptDummy $+\beta_{2}$ Firm Controls $+\beta_{3}$ Industry Controls $+\beta_{4}$ Vesting Dummy $+\epsilon_{i}$

where firm performance is proxied by Tobin's Q; OptDummy is an option dummy variable, which is equal to one if the firms first announced ESOPs and zero otherwise; Industry Controls are industry dummy variables ${ }^{5}$ such as primary, property, energy, services, and goods; Firm Controls are control variables including leverage ratio (long-term debt to total shareholder equity), overinvestment problems, and firm size (natural logarithm of total assets); and Vesting Dummy represents 1-year, 2-year, and 3-year vesting period dummy variables. Lang and Litzenberger (1989), who test the cash flow signaling hypothesis, find that firms pay out dividends to reduce agency costs, thereby alleviating overinvestment problems. We use a dividend dummy of one if companies pay a dividend and zero otherwise. The idea is that, when firms pay a dividend, there is a greater increase in firm performance as it is likely that firms with excessive cash flows will pay out a dividend to avoid overinvestment problems and, at the same time, lower their agency problems.

Equation (7) is run in three variants. The first model involves running a regression on a single independent variable, the ESOPs dummy. In the second model, we include firm-specific characteristics in the ESOP dummy. In the third model, controls for industry effects are added to the second model. For robustness, we employ ROA and ROE as alternative proxies for firm performance.

\footnotetext{
5 Six industrial sectors are tested in this analysis.
} 
We consider an alternative measure of the ESOPs' vesting period effects to see how much value the ESOPs contribute to the firm. We test the following model:

Firm Performance $=\beta_{0}+\beta_{1}$ Opt IV $+\beta_{2}$ Grant Size $+\beta_{3}$ Firm Controls $+\beta_{4}$ Industry Controls $+\epsilon_{i t}$

where Tobin's $Q$ is used for firm performance; Opt IV is the ESOPs' intrinsic value; Grant Size is the natural logarithm of a total number of executive option grants; Firm Controls represent firm size, overinvestment problems, and the leverage ratio; and Industry Controls are dummy variables representing the primary, property, energy, services, and goods industrial sectors. For robustness, we employ stock returns in place of Tobin's $Q$ in Equation (8).

\section{Multivariate Results}

As highlighted earlier in Table 2, firms with ESOPs perform better than non-ESOP firms. The value creation is statistically significant in its cost effectiveness. However, are ESOPs an effective incentive for the alignment of managers' interests with shareholder wealth? Table 3 shows that the performance of ESOP firms increases significantly and positively in years 0, 2 and 3 compared to non-ESOP firms. In Panel A of Table 3, during the year of first announcement of ESOPs, firms with ESOPs witness the highest positive coefficient of 1.83 relative to non-ESOP firms at the $95 \%$ significance level. The strength of the ESOP is even higher two years after the announcement, at the $99 \%$ significance level. The efficacy of the ESOP only tapers off by the third year. These findings are congruent with the thinking that ESOPs, when granted to corporate executives, are an effective incentive for the alignment of their interests to that of their shareholders. Our results are robust ${ }^{6}$ even after controlling for firm-specific characteristics and industry effects, as reported in Table 3, Panels B and C, respectively.

The reported findings are consistent with studies in the US, Germany, Japan, and Singapore, such as those of: (1) Hillegeist and Penalva (2004) and DeFusco et al. (1990), who show that ESOPs in the U.S. add value for corporate practitioners; (2) Langmann (2007), who find that ESOP announcements are associated with positive abnormal returns in Germany; (3) Kato et al. (2005), who report that Japanese investors witness abnormal returns during ESOP announcements; and (4) Ding and Sun (2001), who document increased corporate performance among Singaporean firms that institute ESOPs.

From the firm-specific characteristics results shown in Table 3, Panel B, the leverage ratio has no significant effect on firm value. However, firm size and overinvestment problems indicate some significant results. The firm size result is consistent with the findings of Lang and Stulz (1993). The firm size proxy, the natural logarithm of total assets, is significantly and negatively associated with Tobin's $Q$. This implies that smaller firms tend to outperform larger ones. The dividend dummy as a proxy for overinvestment problems is significantly and negatively related to firm performance one year after the announcement. The result does not support the cash flow signaling hypothesis of Lang and Litzenberger (1989). After controlling for industry effects, the effect of overinvestment problems remains unchanged while firm size becomes less significant in some years.

After ascertaining that ESOPs are positively associated with firm performance, which answers our first research question, Table 4, Panel A reveals the magnitude of the value created by ESOPs for firms that adopt them. Our results report the findings for five years from a firm's establishment of ESOPs, beginning with year 0. The results show that firms issuing ESOPs enjoy significantly higher values starting from the year of their adoption through to four years later, though the level of significance went from $99 \%$ in the first year to $90 \%$ by the fourth year. The regression of Tobin's Q on ESOPs' intrinsic value shows a coefficient ranging from 10.54, which is significant at the $99 \%$ level in year 0 , to 4.66 , which is significant at the $90 \%$ level in year 4 . This trend begins fading away slightly, as do the significance levels. The results imply that the implementation of ESOPs contributes

6 The findings remain even after four years from the first announcement of ESOPs, albeit declining in value compared with the main result in Table 3, Panel A. The yield in year 4 appears to be driven by firm-characteristics and industry effects. 
ten times more value in the initial issuing year of ESOPs and at least four times in year 4 than the cost of adopting the ESOPs. The findings do not change even after controlling for differences in firm characteristics (Table 4, Panel B) and industry effects (Table 4, Panel C).

Table 3. ESOPs and firm performance. This table presents the result of the impact of employee stock option programs on firm performance indicated in six firm-year observations. The first regression is between Tobin's Q and ESOPs dummy, reported in Panel A; the second regression covers the first regression after controlling for Firm-Specific Characteristics, illustrated in Panel B; and Panel C depicts the regression of Tobin's Q on ESOPs dummy after controlling for firm-specific characteristics and Industry Effects. OptDummy is an ESOP dummy variable representing a value of one if the firm first announced ESOPs and zero otherwise; other control variables include log (total assets), leverage ratio and dividend dummy, and five industry dummy variables. T-statistics are shown below each variable and the five bottom lines of the table are adjusted $\mathrm{R}^{2}$, F-statistics, $p$-value, the number of firms with the first ESOPs announcement and the non-ESOP firm. Year -1 refers to a year prior to the first announcement date of ESOPs; Year 0 is a year of the first announcement; and Year 1 to Year 4 represent the years after the announcement. ${ }^{*},{ }^{* *}$ and ${ }^{* * *}$ are $90 \%, 95 \%$ and $99 \%$ levels of significance, respectively.

\begin{tabular}{|c|c|c|c|c|c|c|}
\hline \multicolumn{7}{|c|}{ Panel A: Tobin's Q as a dependent variable and ESOPs dummy as an independent variable } \\
\hline Variable & Year -1 & Year 0 & Year 1 & Year 2 & Year 3 & Year 4 \\
\hline Constant & $1.13^{* * *}$ & $1.15^{* *}$ & $1.26 * *$ & $0.83 * *$ & $0.94 * * *$ & $1.14 *$ \\
\hline OptDummy & 0.59 & $1.83 * *$ & 1.10 & $1.29 * * *$ & $0.60 *$ & 1.07 \\
\hline Adjusted R-squared: & 0.02 & 0.05 & 0.02 & 0.08 & 0.03 & 0.02 \\
\hline F-test & 2.52 & 5.58 & 2.47 & 7.43 & 3.68 & 2.56 \\
\hline$p$-value & 0.12 & 0.02 & 0.12 & 0.01 & 0.06 & 0.11 \\
\hline Number of Companies with ESOPs & 31 & 41 & 40 & 40 & 38 & 38 \\
\hline Number of Companies without ESOPs & 31 & 41 & 40 & 40 & 38 & 38 \\
\hline
\end{tabular}

Panel B: Tobin's $Q$ as a dependent variable and ESOPs dummy as an independent variable after controlling for firm specific characteristics

\begin{tabular}{|c|c|c|c|c|c|c|}
\hline Variable & Year -1 & Year 0 & Year 1 & Year 2 & Year 3 & Year 4 \\
\hline Constant & $2.44^{* * *}$ & $3.88^{* * *}$ & $2.71 * * *$ & $1.85^{* * *}$ & $1.38^{* * *}$ & $4.20^{* * *}$ \\
\hline OptDummy & 0.51 & $1.49 *$ & 0.84 & $1.31^{* * *}$ & $0.62 *$ & $1.12 *$ \\
\hline Leverage Ratio & 0.08 & -0.02 & -0.43 & 0.07 & -0.16 & 0.38 \\
\hline Dividend Dummy & -0.08 & -0.71 & $-2.18 * *$ & 0.52 & 0.10 & 0.68 \\
\hline Log (Total Assets) & $-0.28 * *$ & $-0.48^{*}$ & 0.10 & $-0.31 *$ & -0.10 & $-0.80 * * *$ \\
\hline Adjusted R-squared: & 0.12 & 0.13 & 0.08 & 0.08 & 0.02 & 0.25 \\
\hline F-test & 3.15 & 4.00 & 2.68 & 2.75 & 1.43 & 7.15 \\
\hline$p$-value & 0.02 & 0.01 & 0.04 & 0.03 & 0.23 & 0.00 \\
\hline Number of Companies with ESOPs & 31 & 41 & 40 & 40 & 38 & 38 \\
\hline Number of Companies without ESOPs & 31 & 41 & 40 & 40 & 38 & 38 \\
\hline
\end{tabular}

Panel C: Tobin's $Q$ as a dependent variable and ESOPs dummy as an independent variable after controlling for firm-specific characteristics and industry effects

\begin{tabular}{|c|c|c|c|c|c|c|}
\hline Variable & Year -1 & Year 0 & Year 1 & Year 2 & Year 3 & Year 4 \\
\hline Constant & $3.55^{* *}$ & 4.48 & 4.78 & 0.96 & 1.41 & 4.37 \\
\hline OptDummy & 0.38 & $1.37 *$ & 0.73 & $1.34^{* * *}$ & $0.60 *$ & $1.09 *$ \\
\hline Property & -1.15 & -0.36 & -2.70 & 0.82 & -0.08 & 0.72 \\
\hline Primary & -1.48 & -1.97 & -3.54 & 0.10 & -0.56 & -0.35 \\
\hline Energy & -0.96 & -0.52 & -2.89 & 1.01 & -0.01 & 1.34 \\
\hline Services & -0.72 & -0.26 & -1.99 & 0.63 & -0.03 & 0.10 \\
\hline Goods & -1.57 & -0.52 & -1.62 & 1.52 & 0.26 & -0.14 \\
\hline Leverage Ratio & 0.12 & 0.01 & -0.58 & 0.05 & -0.21 & 0.45 \\
\hline Dividend Dummy & -0.35 & -1.20 & $-2.68 * *$ & 0.51 & 0.06 & 0.54 \\
\hline Log (Total Assets) & $-0.24 *$ & -0.39 & 0.25 & -0.28 & -0.08 & $-0.83^{* * *}$ \\
\hline Adjusted R-squared: & 0.11 & 0.10 & 0.07 & 0.06 & -0.02 & 0.21 \\
\hline F-test & 1.87 & 1.98 & 1.63 & 1.58 & 0.87 & 3.17 \\
\hline$p$-value & 0.08 & 0.05 & 0.12 & 0.14 & 0.56 & 0.00 \\
\hline Number of Companies with ESOPs & 31 & 41 & 40 & 40 & 38 & 38 \\
\hline Number of Companies without ESOPs & 31 & 41 & 40 & 40 & 38 & 38 \\
\hline
\end{tabular}


Table 4. ESOPs and value creation. This table reports Tobin's $Q$, a proxy for firm performance and Opt IV, which is a proxy for ESOPs intrinsic value and is a ratio of a difference between the market price and the exercise price of ESOPs, over the market price in Panel A. Grant Size is the natural logarithm of option grants owned by executives in Panel B. Panel C depicts the result of Tobin's Q after controlling for firm-specific characteristics and industry effects. Leverage Ratio is a proxy for firm leverage; Dividend Dummy is a proxy for overinvestment problems, and the natural logarithm of the total assets is a proxy for firm size, as shown in this table. T-statistics are listed under the coefficient of the variables. Industry dummy variables are a proxy for industry effects. The table also describes the adjusted R-square, F-test and $p$-value at the bottom of the table. Year 0 reflects the year of the first ESOPs issuing; and Year 1 to Year 4 represent the years after issuing. *, ** and ${ }^{* * *}$ indicate $90 \%, 95 \%$ and $99 \%$ levels of significance, respectively.

\begin{tabular}{|c|c|c|c|c|c|}
\hline \multicolumn{6}{|c|}{ Panel A: Tobin's $Q$ regressed on ESOP intrinsic values and controlling for firm-specific characteristics } \\
\hline Variable & Year 0 & Year 1 & Year 2 & Year 3 & Year 4 \\
\hline Constant & $4.62 * * *$ & $3.06^{* * *}$ & $3.072 * *$ & $4.00 * * *$ & $8.35^{* * *}$ \\
\hline Opt IV & $10.54 * * *$ & $8.87^{* * *}$ & $5.20 * *$ & $4.02 * *$ & 4.66 * \\
\hline Log (Total Assets) & $-0.95 *$ & -0.28 & -0.30 & $-0.45^{*}$ & $-1.17 * * *$ \\
\hline Leverage Ratio & 0.14 & -0.20 & -0.17 & -0.16 & -0.12 \\
\hline Dividend Dummy & 0.48 & -1.37 & -0.58 & -0.56 & -0.67 \\
\hline Adjusted R-squared: & 0.34 & 0.39 & 0.12 & 0.17 & 0.41 \\
\hline F-test & 6.25 & 7.29 & 2.26 & 2.60 & 5.29 \\
\hline$p$-value & 0.00 & 0.00 & 0.08 & 0.06 & 0.00 \\
\hline Number of Companies with ESOPs & 41 & 40 & 38 & 33 & 26 \\
\hline \multicolumn{6}{|c|}{ Panel B: Tobin's Q regressed on ESOP intrinsic values and grant size and controlling for firm-specific characteristics } \\
\hline Variable & Year 0 & Year 1 & Year 2 & Year 3 & Year 4 \\
\hline Constant & -3.58 & 3.55 & 0.34 & -0.22 & 0.60 \\
\hline Opt IV & $9.75^{* * *}$ & $8.99 * * *$ & $4.95^{* *}$ & $3.70 *$ & 3.90 \\
\hline Log (Grants Size) & $0.63 *$ & -0.04 & 0.20 & 0.30 & 0.52 \\
\hline Log (Total Assets) & $-0.98^{* *}$ & -0.28 & -0.31 & -0.44 & $-1.13^{* * *}$ \\
\hline Leverage Ratio & 0.20 & -0.18 & -0.05 & -0.07 & -0.19 \\
\hline Dividend Dummy & 0.75 & -1.42 & -0.45 & -0.40 & 0.13 \\
\hline Adjusted R-squared: & 0.39 & 0.37 & 0.09 & 0.14 & 0.38 \\
\hline F-test & 5.89 & 5.42 & 1.68 & 1.97 & 3.97 \\
\hline$p$-value & 0.00 & 0.00 & 0.17 & 0.12 & 0.01 \\
\hline Number of Companies with ESOPs & 40 & 39 & 37 & 32 & 25 \\
\hline \multicolumn{6}{|c|}{ Panel C: Tobin's Q regressed on ESOP intrinsic values and grant size, and controlling for firm-specific characteristics and industry effects } \\
\hline Variable & Year 0 & Year 1 & Year 2 & Year 3 & Year 4 \\
\hline Constant & -6.82 & 2.32 & -6.06 & -3.72 & 2.19 \\
\hline Opt IV & $8.35^{* * *}$ & $8.53^{* * *}$ & $4.90 *$ & $3.59 *$ & 3.67 \\
\hline Grant Size & $0.64 *$ & -0.07 & 0.46 & 0.48 & 0.56 \\
\hline Primary & 0.98 & -0.13 & 1.43 & -0.97 & -4.32 \\
\hline Services & 4.85 & 2.28 & 2.38 & 0.37 & -1.16 \\
\hline Goods & 3.82 & 2.50 & 4.87 & 2.14 & -0.68 \\
\hline Property & 4.45 & 2.48 & 0.70 & -0.88 & - \\
\hline Energy & 5.13 & 1.77 & 1.77 & - & - \\
\hline Log (Total Assets) & $-0.97 * *$ & -0.28 & -0.25 & -0.35 & $-1.22^{* * *}$ \\
\hline Leverage Ratio & 0.27 & -0.23 & 0.19 & -0.01 & 0.06 \\
\hline Dividend Dummy & -0.68 & -1.89 & -0.67 & -0.50 & -0.69 \\
\hline Adjusted R-squared: & 0.36 & 0.32 & 0.13 & 0.11 & 0.38 \\
\hline F-test & 3.24 & 2.80 & 1.54 & 1.45 & 2.82 \\
\hline$p$-value & 0.01 & 0.02 & 0.18 & 0.23 & 0.04 \\
\hline Number of Companies with ESOPs & 40 & 39 & 37 & 32 & 25 \\
\hline
\end{tabular}

The evidence presented thus far is in line with that of Aboody (1996), Hall and Murphy (2002), Hall and Murphy (2003), and Tian (2004), who measure the value of ESOPs using the Black-Scholes option pricing model. We also investigated the impact of ESOP grant size on the firm performance and find that grant size has no meaningful impact on firm performance other than a weak significance at the $90 \%$ level in the year of option grant (Table 4, Panels B and C). We can therefore conclude that ESOPs in New Zealand add value to those issuing them. Firms in New Zealand that adopt ESOPs realize around 10 times larger value than the cost of the ESOPs during the year of issuance. 


\section{Robustness Checks}

To test for the robustness of our findings, we employ ROA and ROE as proxies for firm performance in Equation (7). An analysis of vesting period effects is also considered. Additionally, the rate of stock returns is substituted for Tobin's $Q$ in Equation (8). The results from using ROA and $\mathrm{ROE}$ as proxies for firm performance reveal a weaker positive significance, at the $90 \%$ level, of the effect of ESOPs on firm performance two years after their first announcement (Table 5, Panels A and B). This is consistent with the findings of Elayan et al. (2003), who also find no statistically significant relation between ROA (ROE) and executive compensation in the New Zealand market, and with Cheffou (2007) and Triki and Ureche-Rangau (2012), who report that ESOP announcements are irrelevant to the long-term accounting performance of French firms. After controlling for the impact of different vesting periods, our results reveal that firms that first announced ESOPs continue to outperform their non-ESOP rivals two and three years after the announcement.

Table 5. ESOPs and ROE/ROA. This table shows the results based on ROE and ROA as an alternative proxy for firm performance, which are reported in panels A and B, respectively. Panel C consists of three sub-tables that report the vesting period effects. Tobin's Q in Panel C1, ROA in Panel C2 and ROE in Panel C3 are the test results after considering vesting period effects. OptDummy is the ESOPs dummy variable. Other control variables involve log (total assets), leverage ratio and dividend dummy, and five industry dummies. The table also reports the t-statistics below each variable and the five bottom lines of the table are adjusted $\mathrm{R}^{2}$, F-statistics and $p$-value. Year -1 refers to a year prior to the first announcement date of ESOPs; Year 0 is a year of the first announcement; and Year 1 to Year 4 represent the years after the announcement. *, $* *$ and $* * *$ are $90 \%, 95 \%$ and $99 \%$ levels of significance, respectively.

\begin{tabular}{|c|c|c|c|c|c|c|}
\hline \multicolumn{7}{|l|}{ Panel A: ROE as dependent variable } \\
\hline Variable & Year -1 & Year 0 & Year 1 & Year 2 & Year 3 & Year 4 \\
\hline Constant & $-0.40 * *$ & -1.39 & $-1.06^{* *}$ & $-2.30 *$ & -0.97 & -1.24 * \\
\hline OptDummy & -0.01 & -0.18 & 0.11 & $0.40 *$ & 0.16 & 0.04 \\
\hline Property & 0.24 & 0.16 & 0.21 & 1.06 & -0.37 & -0.08 \\
\hline Primary & 0.19 & 0.61 & 0.35 & 1.43 & 0.14 & 0.16 \\
\hline Energy & 0.16 & 0.15 & 0.25 & 1.13 & -0.47 & -0.27 \\
\hline Services & 0.21 & 0.31 & 0.42 & 1.10 & -0.18 & 0.21 \\
\hline Goods & 0.26 & 0.68 & 0.44 & 1.35 & 0.02 & 0.43 \\
\hline Leverage Ratio & 0.00 & -0.05 & -0.09 & $0.32^{* * *}$ & 0.01 & -0.27 \\
\hline Dividend Dummy & $0.27^{* * *}$ & $0.67 * *$ & $0.49 * * *$ & $0.94^{* *}$ & 0.34 & -0.04 \\
\hline Log (Total Assets) & 0.01 & 0.12 & $0.07 *$ & 0.01 & $0.16 *$ & $0.24 * * *$ \\
\hline Adjusted R-squared: & 0.44 & 0.16 & 0.26 & 0.38 & 0.13 & 0.24 \\
\hline F-test & 6.48 & 2.78 & 4.16 & 6.46 & 2.27 & 3.56 \\
\hline$p$-value & 0.00 & 0.01 & 0.00 & 0.00 & 0.03 & 0.00 \\
\hline Number of Companies with ESOPs & 32 & 42 & 41 & 41 & 38 & 38 \\
\hline Number of Companies without ESOPs & 32 & 42 & 41 & 41 & 38 & 38 \\
\hline \multicolumn{7}{|l|}{ Panel B: ROA as dependent variable } \\
\hline Variable & Year -1 & Year 0 & Year 1 & Year 2 & Year 3 & Year 4 \\
\hline Constant & $-0.34^{* * *}$ & -1.12 & $-0.64 *$ & $-0.78^{* *}$ & -0.07 & -0.23 \\
\hline OptDummy & -0.02 & -0.18 & 0.06 & $0.13 *$ & -0.01 & 0.03 \\
\hline Property & $0.22 *$ & 0.18 & 0.15 & 0.33 & -0.22 & -0.05 \\
\hline Primary & $0.18 *$ & 0.52 & 0.21 & 0.43 & -0.02 & 0.02 \\
\hline Energy & 0.16 & 0.17 & 0.17 & 0.33 & -0.22 & -0.09 \\
\hline Services & $0.19 *$ & 0.26 & 0.27 & 0.40 & -0.16 & 0.00 \\
\hline Goods & $0.22 * *$ & 0.56 & 0.29 & 0.43 & -0.11 & 0.04 \\
\hline Leverage Ratio & $-0.04^{* * *}$ & -0.06 & -0.04 & 0.00 & -0.01 & -0.05 \\
\hline Dividend Dummy & $0.20 * * *$ & $0.51 *$ & $0.29 * * *$ & $0.31 * * *$ & $0.16 *$ & 0.07 \\
\hline Log (Total Assets) & 0.01 & 0.09 & 0.04 & 0.02 & 0.03 & $0.04^{* * *}$ \\
\hline Adjusted R-squared: & 0.48 & 0.10 & 0.22 & 0.16 & 0.08 & 0.18 \\
\hline F-test & 7.58 & 2.08 & 3.57 & 2.67 & 1.68 & 2.85 \\
\hline$p$-value & 0.00 & 0.04 & 0.00 & 0.01 & 0.11 & 0.01 \\
\hline Number of Companies with ESOPs & 32 & 42 & 41 & 41 & 38 & 38 \\
\hline Number of Companies without ESOPs & 32 & 42 & 41 & 41 & 38 & 38 \\
\hline
\end{tabular}

After controlling for vesting period effects, Table 6, Panel A shows that the relation between ESOPs and Tobin's Q remains significant and positive two and three years after 
the first announcement of ESOP adoption. As expected, the relation between vesting periods and firm performance are largely negative and they are significant in years 2 and 3 to account for when most firms set their vesting periods. In Table 6, Panels B and C, it is shown that the ESOPs dummy variable (OptDummy) is positively related to ROA (ROE) two years after the announcement, when taking into consideration vesting period effects.

Table 6. ESOPs and firm performance with vesting period controls. Year 1 to Year 3 represent the years after the announcement. ${ }^{*}, * *$ and ${ }^{* * *}$ are $90 \%, 95 \%$ and $99 \%$ levels of significance, respectively.

\begin{tabular}{|c|c|c|c|}
\hline \multicolumn{4}{|l|}{ Panel A: Tobin's $Q$ as dependent variable } \\
\hline Variable & Year 1 & Year 2 & Year 3 \\
\hline Constant & 5.10 & 0.60 & 0.60 \\
\hline OptDummy & 0.41 & $2.77 * *$ & $3.59^{* * *}$ \\
\hline Property & -3.02 & 0.73 & -0.11 \\
\hline Primary & -3.75 & 0.13 & -0.54 \\
\hline Energy & -2.96 & 1.00 & -0.17 \\
\hline Services & -2.12 & 0.75 & 0.00 \\
\hline Goods & -1.76 & 1.85 & 0.59 \\
\hline Vesting Period Year 1 & -0.03 & $-2.66 * *$ & $-3.63^{* * * *}$ \\
\hline Vesting Period Year 2 & -0.47 & -1.64 & $-2.75^{* * *}$ \\
\hline Vesting Period Year 3 & 0.90 & -0.97 & $-3.41^{* * * *}$ \\
\hline Leverage Ratio & -0.51 & 0.12 & 0.01 \\
\hline Dividend Dummy & $-2.94 * *$ & 0.50 & 0.26 \\
\hline Log (Total Assets) & 0.25 & -0.24 & 0.03 \\
\hline Adjusted R-squared: & 0.04 & 0.10 & 0.20 \\
\hline F-test & 1.29 & 1.70 & 2.61 \\
\hline$p$-value & 0.25 & 0.09 & 0.01 \\
\hline Number of Companies with ESOPs & 40 & 40 & 38 \\
\hline Number of Companies without ESOPs & 40 & 40 & 38 \\
\hline \multicolumn{4}{|l|}{ Panel B: ROE as dependent variable } \\
\hline Variable & Year 1 & Year 2 & Year 3 \\
\hline Constant & $-0.93 *$ & $-2.51 * *$ & -1.15 \\
\hline OptDummy & -0.28 & $1.02 *$ & 0.77 \\
\hline Property & 0.22 & 1.15 & -0.37 \\
\hline Primary & 0.35 & 1.50 & 0.14 \\
\hline Energy & 0.27 & 1.19 & -0.52 \\
\hline Services & 0.39 & 1.18 & -0.18 \\
\hline Goods & 0.38 & 1.43 & 0.08 \\
\hline Vesting Period Year 1 & 0.48 & -0.59 & -0.71 \\
\hline Vesting Period Year 2 & 0.42 & -0.54 & -0.52 \\
\hline Vesting Period Year 3 & 0.38 * & -0.75 & -0.73 \\
\hline Leverage Ratio & -0.04 & $0.34 * * *$ & 0.04 \\
\hline Dividend Dummy & $0.47^{* * *}$ & $1.03 * * *$ & 0.38 \\
\hline Log (Total Assets) & 0.05 & 0.02 & $0.19^{* *}$ \\
\hline Adjusted R-squared: & 0.26 & 0.37 & 0.12 \\
\hline F-test & 3.36 & 4.88 & 1.87 \\
\hline$p$-value & 0.00 & 0.00 & 0.06 \\
\hline Number of Companies with ESOPs & 41 & 41 & 38 \\
\hline Number of Companies without ESOPs & 41 & 41 & 38 \\
\hline
\end{tabular}


Table 6. Cont

\begin{tabular}{|c|c|c|c|}
\hline \multicolumn{4}{|l|}{ Panel A: Tobin's $Q$ as dependent variable } \\
\hline Variable & Year 1 & Year 2 & Year 3 \\
\hline \multicolumn{4}{|l|}{ Panel C: ROA as dependent variable } \\
\hline Variable & Year 1 & Year 2 & Year 3 \\
\hline Constant & $-0.59 *$ & $-0.86^{* *}$ & -0.12 \\
\hline OptDummy & -0.11 & $0.38 * *$ & 0.17 \\
\hline Property & 0.16 & 0.35 & -0.22 \\
\hline Primary & 0.21 & 0.46 & -0.02 \\
\hline Energy & 0.18 & 0.36 & -0.23 \\
\hline Services & 0.26 & 0.43 & -0.15 \\
\hline Goods & 0.26 & 0.46 & -0.07 \\
\hline Vesting Period Year 1 & 0.22 & -0.29 & -0.27 \\
\hline Vesting Period Year 2 & 0.19 & -0.30 & -0.15 \\
\hline Vesting Period Year 3 & 0.16 & -0.27 & -0.19 \\
\hline Leverage Ratio & -0.02 & 0.01 & 0.01 \\
\hline Dividend Dummy & $0.29 * * *$ & $0.34 * * *$ & 0.17 * \\
\hline Log (Total Assets) & 0.03 & 0.03 & 0.04 \\
\hline Adjusted R-squared: & 0.21 & 0.15 & 0.07 \\
\hline F-test & 2.76 & 2.21 & 1.45 \\
\hline$p$-value & 0.00 & 0.02 & 0.17 \\
\hline Number of Companies with ESOPs & 41 & 41 & 38 \\
\hline Number of Companies without ESOPs & 41 & 41 & 38 \\
\hline
\end{tabular}

We consider the robustness of our results on the extent of the value enhancement from ESOPs by using an alternative proxy for firm performance, the rate of stock returns. We report the additional findings in Table 7. Panel A of the table presents the results for the rate of return, in place of Tobin's $Q$, and examine the impact of the ESOP's intrinsic value (Opt IV) in explaining a firm's stock returns. The results reveal that the implementation of the ESOPs culminate in a value addition of 1.23 times the cost of the ESOP during its year of establishment.

In Panels B and C of Table 7, when including grant size into our analysis and controlling for firm characteristics and industry effects, the results remain unchanged. The grant size of ESOPs has the same effect as those reported with Tobin's $Q$ as the dependent variable in Table 4. Similarly, grant size does not have any noteworthy impact on firm performance. 
Table 7. ESOPs and stock returns. This table describes the rate of return as a proxy for firm performance, which is used as a further robustness test. The results of a regression of the rate of return on Opt IV as a proxy for the ESOPs intrinsic value are presented in Panel A. Grant Size is the natural logarithm of option grants owned by executives in Panel B. Panel C depicts the result of the rate of return after controlling for firm-specific characteristics and industry effects. Leverage Ratio is a proxy for firm leverage; Dividend Dummy is a proxy for overinvestment problems; and the natural logarithm of total assets is a proxy for firm size, as shown in this table. T-statistics are listed under the coefficients of the variables. Industry dummy variables are a proxy for industry effects. The table also describes the adjusted R-square, F-test and $p$-value at the bottom of the table. Year 0 reflects the year of the first ESOPs issuing; and Year 1 to Year 4 represent the years after the issuing. * ${ }^{* *}$ and ${ }^{* * *}$ indicate $90 \%, 95 \%$ and $99 \%$ levels of significance, respectively.

\begin{tabular}{|c|c|c|c|c|c|}
\hline \multicolumn{6}{|c|}{ Panel A: Rate of Return regressed on ESOPs intrinsic values after controlling firm-specific characteristics } \\
\hline Variable & Year 0 & Year 1 & Year 2 & Year 3 & Year 4 \\
\hline Constant & 0.03 & $-0.29^{* *}$ & 0.01 & -0.05 & 0.23 \\
\hline Opt IV & $1.23 * * *$ & $0.87 * * *$ & $1.06^{* * *}$ & 0.27 & $0.65 * *$ \\
\hline Log (Total Assets) & -0.03 & 0.05 & -0.07 & 0.01 & -0.06 \\
\hline Leverage Ratio & 0.05 & -0.14 & 0.20 & 0.00 & 0.08 \\
\hline Dividend Dummy & 0.06 & -0.03 & 0.20 & -0.01 & 0.00 \\
\hline Adjusted R-squared: & 0.18 & 0.28 & 0.16 & -0.11 & 0.10 \\
\hline F-test & 3.24 & 4.85 & 2.75 & 0.23 & 1.72 \\
\hline$p$-value & 0.02 & 0.00 & 0.04 & 0.92 & 0.18 \\
\hline Number of Companies with ESOPs & 42 & 41 & 39 & 33 & 26 \\
\hline \multicolumn{6}{|c|}{ Panel B: Rate of Return regressed on ESOPs intrinsic values and grant size after controlling firm-specific characteristics } \\
\hline Variable & Year 0 & Year 1 & Year 2 & Year 3 & Year 4 \\
\hline Constant & -1.17 & -0.63 & 0.45 & 1.63 & 1.21 \\
\hline Opt IV & $1.06^{* *}$ & $0.88^{* * *}$ & $1.14^{* * *}$ & 0.36 & $0.78^{* *}$ \\
\hline Log (Grants Size) & $0.09 *$ & 0.03 & -0.03 & -0.12 & -0.06 \\
\hline $\log (\mathrm{TA})$ & -0.03 & 0.03 & -0.08 & 0.01 & -0.07 * \\
\hline Leverage Ratio & $0.06^{*}$ & -0.13 & 0.20 & -0.05 & 0.10 \\
\hline Dividend Dummy & 0.13 & 0.00 & 0.17 & -0.06 & -0.12 \\
\hline Adjusted R-squared: & 0.18 & 0.28 & 0.14 & -0.06 & 0.10 \\
\hline F-test & 3.24 & 4.85 & 2.22 & 0.64 & 1.56 \\
\hline$p$-value & 0.02 & 0.00 & 0.08 & 0.67 & 0.22 \\
\hline Number of Companies with ESOPs & 42 & 41 & 38 & 32 & 25 \\
\hline
\end{tabular}

Panel C: Rate of Return with option intrinsic value and grant size after controlling firm-specific characteristics and industry effects

\begin{tabular}{|c|c|c|c|c|c|}
\hline Variable & Year 0 & Year 1 & Year 2 & Year 3 & Year 4 \\
\hline Constant & $-1.56^{*}$ & -0.27 & 0.72 & 1.87 & 1.41 \\
\hline Opt IV & $0.96 * *$ & $0.98^{* * *}$ & $1.00 * *$ & 0.36 & $0.71 *$ \\
\hline Log (Grant Size) & $0.11^{* *}$ & 0.03 & -0.02 & -0.13 & -0.06 \\
\hline Primary & 0.08 & -0.21 & -0.52 & 0.04 & -0.16 \\
\hline Services & 0.52 & -0.42 & -0.32 & -0.05 & -0.17 \\
\hline Goods & 0.07 & -0.46 & -0.39 & -0.16 & -0.24 \\
\hline Property & 0.37 & -0.20 & -0.07 & 0.03 & - \\
\hline Energy & 0.63 & -0.25 & -0.11 & - & - \\
\hline Log (Total Assets) & -0.05 & 0.02 & -0.09 & 0.00 & -0.08 * \\
\hline Leverage Ratio & $0.08 * *$ & -0.12 & 0.20 & -0.05 & 0.13 \\
\hline Dividend Dummy & 0.01 & 0.06 & 0.25 & -0.05 & -0.07 \\
\hline Adjusted R-squared: & 0.22 & 0.22 & 0.02 & -0.23 & -0.03 \\
\hline F-test & 2.11 & 2.12 & 1.07 & 0.35 & 0.90 \\
\hline$p$-value & 0.06 & 0.06 & 0.42 & 0.95 & 0.54 \\
\hline Number of Companies with ESOPs & 41 & 40 & 38 & 32 & 25 \\
\hline
\end{tabular}




\section{Conclusions}

This article addresses two research questions pertaining to ESOPs in New Zealand. The first deals with the effect of employee stock options on firm performance. We determine whether firms that announce their first adoption of ESOPs perform better than their nonESOP counterparts. The second question pertains to how much value ESOPs create for the adopting firms. We address these questions in the context of publicly listed firms in New Zealand.

The results of the study show that firms that announce their first adoption of ESOPs significantly outperform their non-ESOP counterparts. These findings are robust even after controlling for firm-specific characteristics and industry effects. We take this to mean that companies in New Zealand believe that ESOPs are an effective incentive for the reduction of agency costs between shareholders and managers. Managerial interest is enhanced when they improve firm performance. How much then is the value created from ESOP adoption? Our findings document that ESOPs are very cost effective to the adopting firms. We show that the implementation of ESOPs contributes to an increase in firm valuation of about 10.5 times relative to their cost at the initiation of the ESOP program. In addition, this increase remains at least four times at year 4 . The general findings hold even after controlling for differences in firm characteristics and industry effects. We also find that the size of the option grant does not impact the firm's performance. We can therefore infer that ESOP use among listed firms in New Zealand is at their individual optimal level.

For a study of this nature, it is inevitable that there will remain some limitations in the data and empirical design. First, due to the limited sample size, the matching process could result in less-than-ideal matches, which may introduce some bias in the results. However, we believe that the impact is minimal as only two companies are affected. Second, the empirical design does not control for a potential selection bias related to the use of ESOPs among start-ups as a substitute for cash compensation. This may result in some of our findings being attributable to firm characteristics rather than the adoption of ESOPs. Third, panel data regressions should ideally cluster the standard errors by firm to minimize Type II error. As our study is focused on the impact of ESOP adoption on firm performance regardless of the age of the firm, these issues are best left to future research.

Author Contributions: Data curation, D.K.D. and Y.E.C.; Formal analysis, D.K.D. and Y.E.C.; Methodology, D.K.D. and Y.E.C.; Writing-original draft, D.K.D. and Y.E.C. Both authors have read and agreed to the published version of the manuscript.

Funding: This research received no external funding.

Institutional Review Board Statement: Not applicable.

Informed Consent Statement: Not applicable.

Data Availability Statement: Data is available upon request.

Conflicts of Interest: The authors declare no conflict of interest.

\section{References}

Aboody, David. 1996. Market valuation of employee stock options. Journal of Accounting and Economics 22: 357-91. [CrossRef]

Aboody, David, and Ron Kasznik. 2000. CEO stock option awards and the timing of corporate voluntary disclosures. Journal of Accounting and Economics 29: 73-100. [CrossRef]

Abowd, John M. 1990. Does performance-based managerial compensation affect corporate performance? Industrial and Labor Relations Review 43: 52S-73S. [CrossRef]

Black, Fischer, and Myron Scholes. 1973. The pricing of options and corporate liabilities. The Journal of Political Economy 3: 637-54. [CrossRef]

Brickley, James A., Sanjai Bhagat, and Ron C. Lease. 1985. The impact of long-range managerial compensation plans on shareholder wealth. Journal of Accounting and Economics 7: 115-29. [CrossRef]

Cheffou, Abdoulkarim I. 2007. Stock options for executives: Determinants for granting and impact on the performance of enterprises, the French case. Paper presented at International Conference of the French Finance Association, Paris, France, May 22-24.

Coase, Ronald H. 1937. The nature of the firm. Economica 4: 386-405. [CrossRef] 
Core, John E., and Wayne R. Guay. 2001. Stock option plans for non-executive employees. Journal of Financial Economics 61: $253-87$. [CrossRef]

Coughlan, Anne T., and Ronald M. Schmidt. 1985. Executive compensation, management turnover, and firm performance: An empirical investigation. Journal of Accounting and Economics 7: 43-66. [CrossRef]

DeFusco, Richard A., Robert R. Johnson, and Thomas S. Zorn. 1990. The effect of executive stock option plans on stockholders and bondholders. The Journal of Finance 45: 617-27. [CrossRef]

Ding, David K., and Qian Sun. 2001. Causes and effects of employee stock option plans: Evidence from Singapore. Pacific-Basin Finance Journal 9: 563-99. [CrossRef]

Elayan, Fayez A., Jammy S. Lau, and Thomas O. Meyer. 2003. Executive incentive compensation schemes and their impact on corporate performance: Evidence from New Zealand since compensation disclosure requirements became effective. Studies in Economics and Finance 21: 54-92. [CrossRef]

Emanuel, David. 2005. Accounting for share-based payments under NZIFRS-2. University of Auckland Business Review 7: 39-44.

Fama, Eugene F., and Michael C. Jensen. 1983a. Agency problems and residual claims. Journal of Law and Economics 26: 327-49. [CrossRef]

Fama, Eugene F., and Michael C. Jensen. 1983b. Separation of ownership and control. Journal of Law and Economics 26: 301-25. [CrossRef]

Hall, Brian J., and Jeffrey B. Liebman. 1997. Are CEOs really paid like bureaucrats? National bureau of Economic Research 113: 654-91.

Hall, Brian J., and Kevin J. Murphy. 2002. Stock options for undiversified executives. Journal of Accounting and Economics 33: 3-42. [CrossRef]

Hall, Brian J., and Kevin J. Murphy. 2003. The trouble with stock options. Journal of Economic Perspectives 17: 49-70. [CrossRef]

Hassan, Hamid, and Yasuo Hoshino. 2007. The performance impacts of stock options in Japan. Japanese Journal of Administrative Science 20: 27-41. [CrossRef]

Hillegeist, Stephen, and Fernando Penalva. 2004. Stock option incentives and firm performance. In IESE Research Papers D/535. New York: IESE Business School.

Huddart, Steven, and Mark Lang. 1996. Employee stock option exercises an empirical analysis. Journal of Accounting and Economics 21: 5-43. [CrossRef]

Jensen, Michael C., and William H. Meckling. 1979. Theory of the firm: Managerial behavior, agency costs, and ownership structure. Journal of Financial Economics 3: 305-60. [CrossRef]

Jensen, Michael C., and Keven J. Murphy. 1990. Performance pay and top-management incentives. Journal of Political Economy 98 : 225-64. [CrossRef]

Kato, Hideaki K., Michael Lemmon, Mi Luo, and James Schallheim. 2005. An empirical examination of the costs and benefits of executive stock options: Evidence from Japan. Journal of Financial Economics 78: 435-61. [CrossRef]

Kurland, Nancy. 2018. ESOP plus Benefit Corporation: Ownership culture with benefit accountability. California Management Review 60: 51-73. [CrossRef]

Lang, Larry H., and Robert H. Litzenberger. 1989. Dividend announcements: Cash flow signalling vs. free cash flow hypothesis? Journal of Financial Economics 24: 181-91. [CrossRef]

Lang, Larry H., and Rene M. Stulz. 1993. Tobin's q, corporate diversification and firm performance. Journal of Political Economy 102: 1248-80.

Langmann, Christian. 2007. Stock market reaction and stock option plans: Evidence from Germany. Schmalenbach Business Review 59: 85-106. [CrossRef]

Leonard, Jonathan S. 1990. Executive pay and firm performance. Industrial and Labor Relations Review 43: 13S-29S. [CrossRef]

Meulbroek, Lisa K. 2000. The efficiency of equity-linked compensation: Understanding the full cost of awarding executive stock options. Financial Management 30: 5-44. [CrossRef]

Mirrlees, James A. 1976. The optimal structure of incentives and authority within an organization. The Bell Journal of Economics 7: 105-31. [CrossRef]

Morgenson, Gretchen. 1998. Stock options are not a free lunch. Forbes 161: 212-17.

Murphy, Kevin J. 1985. Corporate performance and managerial remuneration: An empirical analysis. Journal of Accounting and Economics 7: 11-42. [CrossRef]

Murphy, Kevin J. 1999. Executive compensation. Handbook of Labor Economics 3: 2485-563. [CrossRef]

Paquette, Peter C. 2010. A Methodology for Determining the Shareholder Value Created by a Sustainable ESOP Company. Journal of Employee Ownership Law and Finance 22: 31-54.

Popescu, Cristina R. G., and Gheorghe N. Popescu. 2019. An exploratory study based on a questionnaire concerning green and sustainable finance, corporate social responsibility, and performance: Evidence from the Romanian business environment. Journal of Risk and Financial Management 12: 162. [CrossRef]

Riaz, Fayyaz, Fiza Abdul Razzaq, and Ahsan Waqar. 2017. Effect of Employee Stock Ownership Plans (ESOPs) on the Performance of Small Business in Karachi. MPRA Paper No. 84322. Available online: https://mpra.ub.uni-muenchen.de/84322/ (accessed on 1 October 2020).

Ross, Stephen A. 1973. The economic theory of agency: The principal's problem. The American Economic Review 63: 134-39.

Shleifer, Andrei, and Robert W. Vishny. 1997. A survey of corporate governance. The Journal of Finance 52: 737-83. [CrossRef] 
Si, Deng-Kui, Yanan Wang, and Dongmin Kong. 2020. Employee incentives and energy firms' innovation: Evidence from China. Energy 212: 118673. [CrossRef]

Stiglitz, Joseph E. 1975. Incentives, risk, and information: Notes towards a theory of hierarchy. The Bell Journal of Economics 6: 552-79. [CrossRef]

Tian, Yisong S. 2004. Too much of a good incentive? The case of executive stock options. Journal of Banking E Finance 28: $1225-45$.

Triki, Thouraya, and Loredana Ureche-Rangau. 2012. Stock options and firm performance: New evidence from the French market. Journal of International Financial Management \& Accounting 23: 154-85.

Yermack, David. 1997. Good timing: CEO stock option awards and company news announcements. Journal of Finance 52: 449-76. [CrossRef] 